\title{
КІБЕРНЕТИЧНА ОДНОКОМПАРТМЕНТНА МОДЕЛЬ ДИНАМІКИ ГЛІКЕМІЇ ПРИ ПОРУШЕННЯХ ГЛЮКОЗНОГО ГОМЕОСТАЗУ*
}

\author{
Микитюк М. P. ${ }^{1,4}$, Хижняк O. O., ${ }^{1,4}$ Сокол С. I. ${ }^{2}$, \\ Лапта С. С. ${ }^{2}$, Соловйова O. I. ${ }^{3}$, Романова I. П. ${ }^{1}$ \\ ${ }^{1}$ ДУ «Інститут проблел ендокринної патологї̈ ім. В.Я. Данилевського НАМН України, \\ м. Харків, Україна; \\ ${ }^{2}$ Національний технічний університет "ХПI», м. Харків, Украӥна; \\ ${ }^{3}$ Харківський національний університет Повітряних Сил іл.І. Кожедуба, \\ м. Харків, Украӥна; \\ ${ }^{4}$ Харківська медична академія післядипломної освіти, м. Харків, Украйна \\ myroslavamk@ukr.net
}

В останні десятиріччя відзначаеться явна тенденція до зростання захворюваності на цукровий діабет (ЦД). За прогнозами експертів Міжнародної Діабетичної Федерації та Всесвітньої організації охорони здоров'я до 2030 року очікуеться понад 552 млн осіб із маніфестними порушеннями глюкозного гомеостазу $[1,2]$. Щорічно в світі рееструеться більше 609 тисяч випадків ЦД de novo. 3 огляду на медико-соціальну значущість проблеми ЦД, важливо своєчасно виявляти порушення глюкозного гомеостазу на ранніх стадіях.
Відомо, що головні чинники регуляції глюкозного гомеостазу, глікемія і інсулінемія, пов'язані оберненим негативним зв'язком [3]. Це дозволяе у відповідній математичній моделі виразити змінну інсулінемії через змінну глікемії і отримати найбільш мінімальну математичну модель системи регуляції глюкозного гомеостазу у вигляді моделі динаміки глікемії з опосередкованим урахуванням інсулінемії через саму глікемію.

За останні півстоліття було запропоновано багато математичних моделей та їх

* Роботу виконано в межах планової наукової тематики ДУ «Інститут проблем ендокринної патології ім. В. Я. Данилевського НАМН України» «Удосконалити діагностику неалкогольної жирової хвороби печінки у хворих на цукровий діабет 2 типу за урахуванням етіопатогенетичних механізмів розвитку захворювання» (державний реєстраційний номер 0119U102446

Установою, що фінансуе дослідження, е НАМН України.

Роботу виконано в межах планової наукової тематики Національного технічного університету «ХПІ» «Метод телеметричного комп'ютерного контролю та діагностики стану здоров'я людини за результатами вимірювання апріорі невизначених біоелектричних сигналів» (ДР № 0110U001246).

Установою, що фінансуе дослідження є МОН України.

Автори гарантують повну відповідальність за все, що опубліковано в статті.

Автори гарантують відсутність конфлікту інтересів і власної фінансової зацікавленості при виконанні роботи та написанні статті.

Рукопис надійшов до редакції 16.07.2021. 
варіацій, які номінально описують роботу системи регуляції глюкозного гомеостазу, що відображено, наприклад, у огляді [4]. Однак, практично усі вони стосуються лише окремих проявів цієї системи в обмежених випадках їі спостереження. Це емпіричні моделі типу «чорної скриньки» за Н. Вінером [5] та їх узагальнення у вигляді гіпотетичних номінально змістовних структурно-морфологічних моделей [4].

Виняток становить модель динаміки глікемії [5], яка без залучення гіпотез описує цілком глікемічні криві клінічних тестів толерантності до глюкози: внутріш- ньовенного (ВТТГ) і перорального (ПТТГ). Проте, як виявилося, ця модель не відтворює дані модифікації ПТТГ з повторним глюкозним навантаженням (per os 50 г глюкози двічі з інтервалом 1 година 3 визначенням рівня глікемії кожні 30 хвилин протягом трьох годин), відомого як проба Штауба-Трауготта (ПТТГ2) [7, 8].

Метою даної роботи є розробка математичної моделі системи регуляції вуглеводного обміну у вигляді моделі динаміки глікемії, придатної для опису усіх відповідних клінічних даних.

\section{МАТЕРІАЛИ ТА МЕТОДИ}

Для побудови такої моделі було застосовано розвинуте для цього узагальнення і поглиблення відомого кібернетичного методу Н. Вінера [5], визначення структури досліджуваної складної системи (у нашому випадку - системи регуляції гомеостатичного рівня глікемії) у вигляді оберненого негативного зв’язку за її відгуком на заданий вхідний сигнал. Узагальнення полягає у введенні відповідно до клінічних даних цілої низки обернених негативних зв'язків, керуючих динамікою глікемії.

Для розрахунку математичної моделі використані дані, отримані при проведені ППТГ у 89 осіб, що знаходилися на ліку- ванні в клініці ДУ «Інститут проблем ендокринної патології ім. В. Я. Данилевського НАМН України». На рис. 1 наведені у графічному вигляді, як літературні, так і оригінальні, вид функцій $f_{\mathrm{V}}(t)(1)$ внутрішньовенної ін'єкції глюкози, а також $f_{p}(t)(2)$ їі всмоктування в кров з кишечнику пацієнта в нормі отримана в роботі [4].

Рівень глікемії натще і впродовж ПТТГ визначали в плазмі капілярної крові глюкозооксидазним методом на аналізаторі «Biosen C-line» (EKF, Німеччина). Діапазон визначення рівня глюкози становив 0,550,0 ммоль/л; допустиме значення відносного відхилення - не більше 4,5\%.

\section{РЕЗУЛЬТАТИ ТА ЇХ ОБГОВОРЕННЯ}

Як видно з графіків динаміки глікемії $g(t)$ на рис. 1 , система їі саморегуляції поводить себе по різному у залежності від способу її виведення із базального стану $g_{b}$, тобто в цих випадках проявляють себе різні механізми оберненого негативного зв'язку. Притаманні системі в цілому, ці механізми присутні при її довільному глюкозному навантаженні, однак чітко виявляють свій парціальний внесок в регуляцію лише в деяких обставинах. У більшості випадків їх дія непомітна на тлі інших превалюючих фракторів.

Найбільш зручною для виявлення окремих каналів оберненого негативного зв’язку в системі саморегуляції рівня глікемії $е$ глікемічна крива ВТТГ в нормі (рис. 1.1.а) завдяки короткочасному, до того ж контрольованому глюкозному навантаженню $f_{V}(t)$
(1). Початок їі зниження відповідае традиційному оберненому негативному зв'язку за поточним позитивним відхиленням $y(t)=g(t)-g_{b}>0$ рівня глікемії $g(t)$ від його базального значення $g_{b}$ (уставки), За ціею регуляціею швидкість повернення змінної $g(t)$ до її базального рівня $g_{b}$, тобто її похідна $g^{\prime}(t)=y^{\prime}(t)$, визначаеться величиною відхилення $y(t): y^{\prime}(t)=-\gamma y(t), \gamma>0$.

Наявність у ціеї кривої осциляції при їі наближенні до базального рівня $g_{b}$ можна пояснити тільки додатковим каналом оберненого негативного зв'язку: теж за відхиленням рівня глікемії $g(t)$ від тієї ж уставки тільки із змінним знаком і з деяким суттевим запізненням $\tau: y(t-\tau)$.

Крім того, треба відзначити, що клінічно-довідникове значення підйому гліке- 

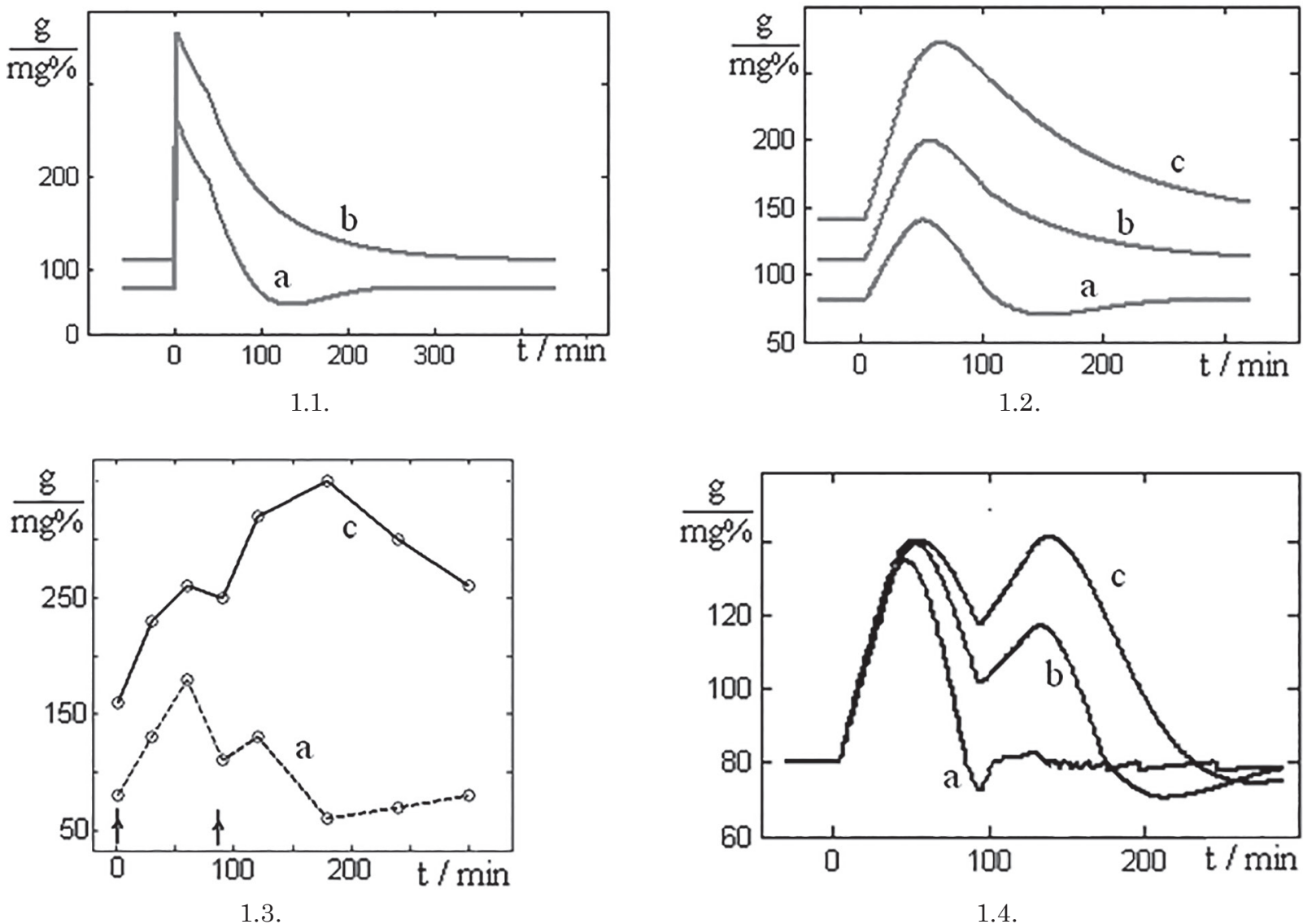

1.4 .

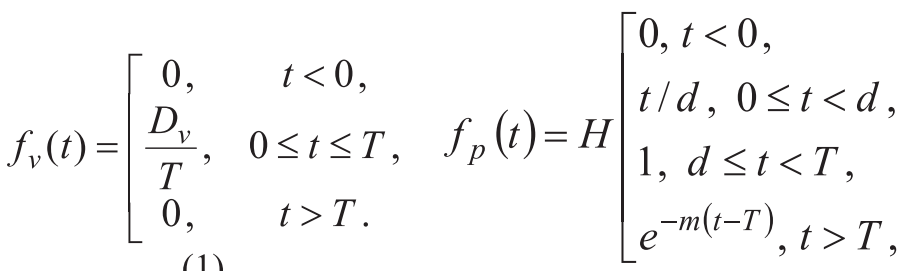
(1)

1.5 .
1.6 .

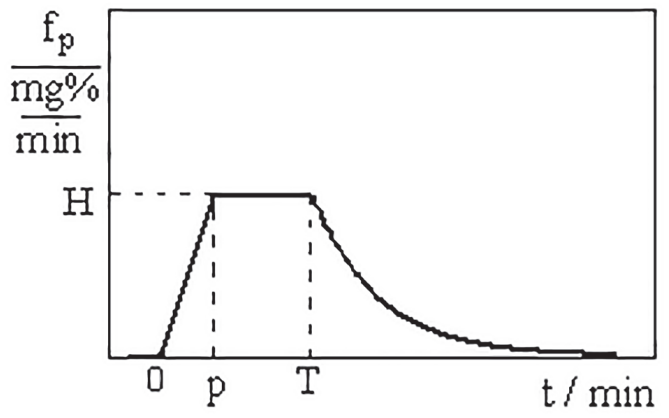

1.7.

Рис. 1. Глікемічні криві

(a - відповідають нормі; b - порушенню толерантності до глюкози; с - ЦД 2-го типу:

1.1 - при ВТТГ; 1.2 - при ПТТГ; 1.3 - при ПТТГ2 клінічні дані з роботи [7];

1.4 - сімейство розрахункових кривих ПТТГ2 моделі (4); 1.5 - фрункція $f_{V}(t)$ інтенсивності ін'єкціі глюкози при ВТТГ; 1.6, 1.7 - функція $f_{p}(t)$ інтенсивності всмоктування глюкози в кров при ПТТГ і її графік з роботи [5].

мічної кривої стандартного ВТТГ у нормі на рис. 1.1.а є у 2,8 рази меншим, ніж його розрахункова величина відповідно введеному глюкозному навантаженню $f_{V}(t)(1)$. Це свідчить про те, що в системі регуляції рівня глікемії існуе і зараз проявляеться ще один канал оберненого негативного зв'язку за швидкісним сигналом - інтенсивністю $f_{V}(t)$ надходження глюкози до крові: $\left(-\alpha f_{V}(t)\right.$, де $a>0$ - число), який утилізуе додаткову глюкозу в ній.

Тому модель системи саморегуляції рівня глікемії при ВТТГ з трьома визначеними каналами зворотного негативного зв'язку, в якій задля повноти враховано ще пасивний регуляторний механізм глюкозурії з інтенсивністю $u_{g l}(t)=\delta\left(g(t)-g^{*}\right)^{+}$при перевищенні рівнем глікемії $g^{*}$ ниркового по- 
рогу $g^{*}$ реабсорбції глюкози $(\delta>0)$ - число), приймає вигляд рівняння (3):

$y^{\prime}(t)=(1-\alpha) f_{v}(t)-\beta y(t-\tau)-\gamma(y(t-1))^{+}-\delta\left(g(t-1)-g^{*}\right)^{+}, t \geq 0$, $y(t)=\phi(t)=0,-\tau \leq t \leq 0$.

в якому символом $(z)^{+}$позначено порогову фрункцію, яка приймає значення $z$ при $z \geq 0$ і 0 при $z<0$.

Це диференціальне рівняння (3) з аргументами, що спізнюються на одну хвилину (час обороту крові по замкненому кровоносному руслу) і на $\tau \geq 1$ хвилин, для однини розв'язку потребує завдання початкової фрункції $\varphi(t)$.

Очевидно, що система регуляції глюкозного гомеостазу $є$ інваріантною до шляху надходження у кров екзогенної глюкози: внутрішньовенно чи перорально, за виключенням впливу гастроентерального гормону, який, як відомо [1], підсилює гіпоглікемізуючу дію інсуліну.

Такою ж має бути і відповідна математична модель (3), в якій фрунція інтенсивності надходження до крові екзогенної глюкози має вигляд $f_{V}(t)(1)$ або $f_{p}(t)(2)$. Тобто значення усіх параметрів моделі (3), окрім параметра $a$, ідентифікованих за клінічними даними визначеного пацієнта, мають бути однаковими у разі даних ВТТГ (рис. 1.1.a) і у разі даних ПТТГ (рис. 1.2.а).

Перевірка цієї інваріантності значень параметрів моделі (3) у зв'язку з відсутністю необхідного для цього клінічного матеріалу була проведена на довідникових глікемічних даних ВТТГ і ПТТГ «умовного усередненого пацієнта» [8]. При цьому, як і передбачалося, в обох випадках тестів були отримані одні й ті ж значення параметрів моделі (3): $\beta=0,015 x 8^{-1} ; \gamma=0,010 x 8^{-1}$; $\mathrm{\tau}=35 x в ; \delta=0,0375 x_{8^{-1}} ; \mathrm{g}^{*}=180 \mathrm{mg} / \mathrm{dl}$ i різні значення параметра $a: a_{v}=0,644$ i $a_{p}=0,946$.

Глікемічні дані ПТТГ2 на рис. 1.3 дозволили виявити в системі саморегуляції рівня глікемії існування ще одного каналу оберненого негативного зв'язку по накопичувальному інтегральному фрактору — повній кількості екзогенної глюкози $Q(t)$, що безперервно надійшла до крові. При припиненні надходження глюкози у кров (розриві безперервності) цей накопичувальний фактор обнуляється з подальшим початком нового накопичення.

Без урахування дії цієї регуляції модель (3) при описі динаміки глікемії у разі введення тісно наступних один за одним пероральних глюкозних навантажень, як при ПТТГ2, показує просту суперпозицію дій кожного з них окремо. Проте, при клінічному проведенні ПТТГ2 з частковим перетином у часі двох пероральних навантажень спостерігається явище ШтаубаТрауготта: у загальній їх дії у здорового пацієнта парціальний внесок другого 3 них пригнічуеться значно або навіть повністю (рис. 1.3.а) [7]. У разі ж порушеної толерантності до глюкози, або ЦД 2 типу парціальний внесок другого навантаження в загальну динаміку глікемії ПТТГ2 не зменшується, а може навіть збільшитися (рис. 1.3.с).

При доповненні моделі (3) цією регуляцією за інтегральним накопичувальним фрактором і узагальненні їі на введення як внутрішньовенної, так і пероральної екзогенної глюкози, вона приймає вигляд рівняння (4) і описує сімейство глікемічних кривих ПТТГ2 на рис. 1.4.

$$
\begin{aligned}
& y^{\prime}=\left(1-\alpha_{v}\right) f_{v}(t)+\left(1-\alpha_{p}\right) f_{p}(t)-\beta y(t-\tau)- \\
& -\gamma y^{+}(t-1)-\chi Q(t-1)-\delta\left(g(t-1)-g^{*}\right)^{+}, t \geq 0, \\
& y(t)=\phi(t), \phi(t)=0,-\tau \leq t \leq 0
\end{aligned}
$$

Усі параметри моделі (4) мають певний фізіологічний сенс і однозначно знаходяться за клінічними даними ВТТГ або ПТТГ пацієнта, тому вони можуть бути використані у якості діагностичних.

Так параметр $a\left(a_{v}\right.$ при ВТТГ і $a_{p}$ при ПТТГ) описує внесок в регуляцію динаміки глікемії першого фрактору секреції інсуліну 8 -клітинами підшлункової залози, пов'язаного зі швидкістю $\left(f_{V}(t)\right.$ або $\left.f_{p}(t)\right)$ надходження в кров екзогенної глюкози. Збільшення значення параметра $a_{p}$ відносно значення параметраaаv $\alpha_{v}$ у одного й того ж пацієнта обумовлено посиленням дії інсуліну гастроентеральним гормоном. Аналогічно, добуток в рівнянні (4) параметра х на повну кількість екзогенної глюкози $Q(t)$, що безперервно надійшла до кровi, описує другий фрактор секреції інсуліну 
В-клітинами підшлункової залози за його визначенням [3]. (Ці фактори секреції інсуліну спостерігалися фізіологами у вигляді фаз тільки в ВТТГ [3]).

Параметри 8 і ү, які в моделі (4) описують зворотний негативний зв'язок в регуляції рівня глікемії за його відхиленням від базального рівня (миттевого чи з запізненням т) є типовими для багатьох фізіологічних процесів і інтегрально описують їх. Це стосуеться як інсулінової, так і без інсулінової регуляції, а також дії контрінсулінових гормонів, які працюють на підвищення рівня глікемії.

Таким чином, регуляторна дія інсуліну є багатогранною і здійснюеться як за параметрами відхилення регульованого рівня глікемії від базального стану, так і за динамічним параметром швидкості виведення рівня глікемії від нього, а також за інтегральним параметром всієї безперервно введеної до крові екзогенної глюкози.

Модель (4) містить параметри з невизначеними значеннями у зв'язку з варіабельністю відповідних характеристик у різних паціентів. Індивідуалізація моделі до кожного пацієнта (ідентифікація вектора $X\left(\alpha, \beta, \gamma, x, \tau, \delta, g^{*}, g_{b}\right)$ ï параметрів) проводиться багатовимірним комп'ютерним їх підбором за його клінічними даними ПТТГ. При цьому реально визначаються значення тільки перших п'яти параметрів вектора $X$, значення інших трьох його параметрів знаходяться окремо заздалегідь. Критерій близькості розрахункових модельних і клінічних даних паціента оцінюеться відповідно до методу найменших квадратів за функціоналом $F(X)(5)$ неув'язки між розрахунковими $y\left(t_{m}, X\right)$ і клінічними $y_{k}\left(t_{m}\right)$ значеннями глікемії з додатковим нормуванням на кількість вимірів $N$ :

$$
F(X)=\frac{1}{N} \sqrt{\sum_{m=1}^{N}\left|\frac{y\left(t_{m}, X\right)-y_{k}\left(t_{m}\right)}{y\left(t_{m}, X\right)}\right|^{2}} .
$$

Мінімізація цільової функції (5) проводиться комбінацією прямих і градієнтних методів в операційному середовищі Matlab-6.

\section{ВИСНОВКИ}

1. Запропонована найбільш мінімальна кібернетична однокомпартментна математична модель системи регуляції глюкозного гомеостазу у вигляді моделі динаміки

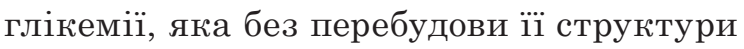

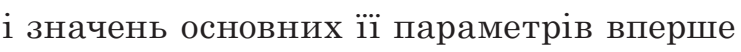
адекватно відтворюе глікемічні дані пацієнта, отримані при проведенні у нього довільного глюкозотолерантного тесту: внутрішньовенного, перорального чи проби Штауба-Трауготта.

2. Усім параметрам нової моделі надано певний фізіологічний сенс. Їх значен- ня однозначно знаходяться при індивідуалізації моделі до пацієнта за його клінічними даними, зокрема даними ПТТГ, в процесі ї̈ параметричної ідентифікації при мінімізації цільової функції неув'язки між розрахунковими і клінічними значеннями глікемії.

3. Параметри моделі, індивідуалізованої до паціента за його клінічними даними, можуть бути використані у якості діагностичних, характеризуючи стан системи регуляції глюкозного гомеостазу у нього. 


\title{
ЛITEPATУРA \\ (REFERENCES)
}

1. International Diabetes Federation. Diabetes Atlas. 5th ed, available at: http://www.idf.org/atlasmap/atlasmap.

2. World Health Organization. Obesity: Global status report on noncommunicable diseases 2010, Geneva, 2011: 176 p.

3. Genes SG, Zhurova MV, Poltorak VV. Problemy Jendokrinologii 1980;26(5): 73-79.

4. Karpel'ev VA, Filippov JuI, Tarasov JuV, et al. Vestn Ros Akad Med Nauk 2015;70(3): 549-560. https://doi. org/10.15690/vramn.v70.i5.1441.

5. Viner N. Kibernetika ili upravlenie i svjaz' v zhivotnom i mashine, Moskva, 1968: 328 p.

6. Lapta SI, Lapta SS, Solov'eva OI. Funkcional'no-strukturnoe matematicheskoe modelirovanie slozhnyh gomeostaticheskih sistem: monografija, Harkiv, 2009: 332 p.
7. Kamyshnikov VS. Metody klinicheskih laboratornyh issledovanij, Moskva, 2016: 736 p.

8. Perederij VG, Tkach SM. Osnovy vnutrennej mediciny: v 3 t. T. 1. Zabolevanija organov dyhanija. Zabolevanija organov pishhevarenija. Zabolevanija sistemy krovi i krovetvornyh organov. Zabolevanija jendokrinnoj sistemy, Kiev, 2009: 783 p.

9. Jenciklopedija klinicheskih laboratornyh testov : perevod s angl; za red.: VV. Men'shikova, Odesa, 1997: $960 \mathrm{p}$.

\section{КІБЕРНЕТИЧНА ОДНОКОМПАРТМЕНТНА МОДЕЛЬ ДИНАМІКИ ГЛІКЕМІІ̄ ПРИ ПОРУШЕННЯХ ГЛЮКОЗНОГО ГОМЕОСТАЗУ}

\author{
Микитюк М. P., ${ }^{1,4}$ Хижняк O. O., ${ }^{1,4}$ Сокол С. I. ${ }^{2}$, \\ Лапта С. С. ${ }^{2}$, Соловйова О. I. ${ }^{3}$, Романова I. П. ${ }^{1}$ \\ ${ }^{1}$ ДУ «Інститут проблем ендокринної патологї ім. В.Я. Данилевського НАМН України, \\ м. Харків, Україна; \\ ${ }^{2}$ Національний технічний університет "ХПI», м. Харків, Украӥна; \\ ${ }^{3}$ Харківський національний університет Повітряних Сил ім.І. Кожедуба, \\ м. Харків, Україна; \\ ${ }^{4}$ Харківська медична академія післядипломної освіти, \\ м. Харків, Україна \\ myroslavamk@ukr.net
}

Медико-соціальні проблеми цукрового діабету, спричинені порушеннями в системі регуляції вуглеводного обміну, привели до глибокого рівня її досліджень, достатнього для опису засобами математичного моделювання. Розроблені до цього часу моделі стосуються лише окремих проявів поведінки ціеї системи. Без будь-яких гіпотез при математичному моделюванні системи регуляції вуглеводного обміну пропонуеться їі кібернетична мінімальна математична модель у вигляді однокомпартментної моделі динаміки глікемії із опосередкованим урахуванням інсулінемії. Ця модель, не зважаючи на простоту, при довільному глюкозному навантаженні, без зміни її структури та без зміни значень

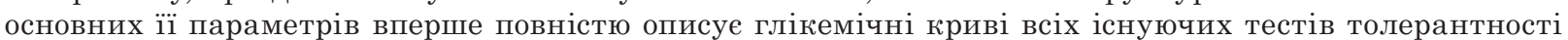
до глюкози та дозволяе вирішити практичні питання об'ективної діагностики. У роботі використано узагальнення кібернетичного методу Н. Вінера визначення структури досліджуваної складної системи у вигляді негативного зворотного зв'язку за ї̈ реакцією на заданий вхідний сигнал. У дослідженні використані клінічні дані тестів толерантності до глюкози та аналітичний вигляд фуннкцій внутрішньовенного та перорального надходження екзогенної глюкози в кров. Нова модель представляє собою диференціальне рівняння першого порядку із запізненням аргументу, яке при чисельному аналізі зводиться до рекуррентної формули, зручної до роботи. Усім параметрам моделі надано певний фізіологічний сенс. Їх значення однозначно знаходяться при індивідуалізації моделі до паціента за його клінічними даними в процесі її параметричної ідентифікації при мінімізації цільової фрункції неув’язки між розрахунковими та клінічними значеннями глікемії. Параметри моделі, індивідуалізованої до паціента за його клінічними даними, можуть бути використані як діагностичні.

Ключові слова: цукровий діабет, система регуляції вуглеводного обміну, динаміка глікемії, математична модель. 


\title{
CYBERNETIC ONE-COMPARTMENT MODEL OF GLYCEMIA DYNAMICS IN GLUCOSE HOMEOSTASIS DISORDERS
}

\author{
Mykytyuk M. R ${ }^{1,4}$, Khyzhnyak O. O..,4, Sokol Y. I. ${ }^{2}$, \\ Lapta S. S. ${ }^{2}$, Soloviova O. I. ${ }^{3}$, Romanova I. P. ${ }^{1}$ \\ ${ }^{1}$ State Institution «V. Danilevsky Institute for endocrine pathology problems \\ National Academy of Medical sciences of Ukrainen, Kharkiv, Ukraine; \\ ${ }^{2}$ National Technical University "KhPI», Kharkiv, Ukraine, \\ ${ }^{3}$ Ivan Kozhedub Kharkiv National University of the Air Force, Kharkiv, Ukraine; \\ ${ }^{4}$ Kharkiv Medical Academy of Postgraduate Education, Kharkiv, Ukraine \\ myroslavamk@ukr.net
}

The medical and social problems of Diabetes mellitus caused by disorders in the system of carbohydrate exchange regulation have led to a deep level of its research, sufficient to describe it in mathematical modelling terms. The models, which have so far been developed, refer only to separate manifestations of the behaviour of this system. The carbohydrate exchange regulation system minimal mathematical model is proposed in the form of the one-compartment model of glycemic dynamics with indirect regard to insulinemia. This model at an arbitrary glucose load, without reconstructing its structure and without changing the values of its main parameters for the first time fully describes the glycemic curves of all existing glucose tolerance tests and allows solving practical questions of objective diagnosis. The paper uses the generalization of Wiener's method for clarification the structure of the studied complex system in the form of negative feedback connection according to its response to a given input signal. The investigation used clinical data of glucose tolerance tests and the analytical view of the function of intravenous and oral intake of exogenous glucose into the blood. The new model represent the differential equation of the first order with delayed argument, which, in numerical analysis is reduced to a recurrent formula. To parameters of the model are given the physiological meaning. Their values are unambiguously found when the model is individualized to the patient according to clinical data in the process of parametric identification while minimizing the objective function of the discrepancy between the calculated and clinical values of glycemia. The parameters of the model, individualized to the patient according to his clinical data, can be used as diagnostic.

Key words: diabetes mellitus, system of carbohydrate exchange regulation, dynamics of glycemia, mathematical model.

Микитюк М. $P$.

ORCID: https://orcid.org/0000-0002-6169-7628;

Хижняк О. О.

ORCID: https://orcid.org/0000-0002-4541-5248;

Сокол $\boldsymbol{C}$. I.

ORCID: https://orcid.org/0000-0002-5278-9272;

Janma C. C. ORCID: https://orcid.org/0000-0002-0738-572X;

Соловйова О. I.

ORCID: https://orcid.org/0000-0003-4403-9532. 